\title{
Development of Open Journal System 3.0
}

\author{
Yoris Adi Maretta*, Totok Sumaryanto, Yuli Utanto, Kustiono Kustiono, and Sri Maryati Deliana \\ Universitas Negeri Semarang, Indonesia
}

\begin{abstract}
This study aims to develop an Open Journal System 3.0 and test the effectiveness of the open journal system 3.0 as a media student learning resources. This research method using research procedures Research and Development. The results showed acquire material expert assessment of the percentage of $94.44 \%$ while the assessment of media experts journals obtain a percentage of $97.77 \%$. The results of testing the effectiveness of $t$ count $>t$ table $(20$ 945> 2.000) and significance $<0.05(0.000<0.05)$, then Ho is rejected. So we can conclude there are differences in the effectiveness of this research on the development of open journal 3.0 system that is used as a medium for student learning resources. This may imply that the development of open journal 3.0 system influence on student effectiveness in finding learning resources and the ease of downloading the article.
\end{abstract}

\section{Introduction}

Website E-Journal lecturers and students using the platform Open Journal System 3.0. Open Journal System 3.0 is a management platform of scientific journals online. OJS 3 enables journal managers to migrate from offline to online management system. Starting from a manuscript / article posted by the author, the process of reviewing, tracking, and so forth until the manuscript is accepted for publication in a journal, everything can be done with OJS 3 [1]. According Willinsky (2005) with this system the process of sending manuscripts / articles (submission), assessment, editing, layout editing and publishing can be done online. OJS 3 itself was developed by the Public Knowledge Project (PKP). Public Knowledge Project is an organization founded in 1998 by John Willinsky University of British Columbia. Since then PKP has grown and evolved into a virtual operation with two international and institutional anchor at Stanford University and Simon Fraser University Library [2].

OJS 3 is a web-based information system, so it requires Apache web server and recommended using a serverbased, such as debian, ubuntu, redhat, Suse and other OS servers [3]. Comparison with the media website management journals such as wordpress, jomla, Moodle, the OS server on OJS 3-based This has the advantage especially of better security, faster access, lightweight system and also the software that is free and freely developed by anyone [4]

Unnes problems faced during this time was to see Open Journal System 3.0 is fairly standard and rigid, making the reader / user difficult to operate. During this time the reader is hard to find the desired article in the online journal. Whether it's the students and faculty. In addition to these problems, the difficulty in accessing the posting, journal editors list, see the visitor counter is not clearly visible because the view is still the standard. Not only that issue, see the layout of the article also does not meet the national standard layout journal articles. There are still some weaknesses, such as web E-Journal, volume, issue, the issue of the journal, correspondence address, date received, approved and published and issued by whom also lacking [5].

\section{Methods}

This research method using research procedures Research and Development. Research and Development can be defined as the research methods used to produce a specific product and test the effectiveness of these products [6]

Before doing the development, the first data collection. In this phase, three ways of collecting data that is observation, interviews and questionnaires. Observation is a method of collecting data using observations of the research object [5]. Data collection techniques such as observation and interviews intended to seek potential and problems that have been experienced by visitors of the students in the sample. Observations and interviews were conducted by visiting the Office Developer Library Journal Unnes Building G Floor 1 Campus Unnes sekaran Gunungpati [7].

\section{Results and Discussion}

Samples are partly or representative of the population studied. The use of the test was given to 51 students a sample of the population of students from the Department of Education Technology totaling 334 students. Consisting of $15 \% 1,3,5,7$ semester students. The population is the totality of all possible values, the results of counting or measurement, quantitative and qualitative data about the particular characteristics of all members of a collection of complete and clear we want to learn its properties [8]

A number of written questions questionnaire was used to obtain information from respondents in terms of his personal report, or the things he knew. In the test phase of use, provides research to a sample questionnaire to distinguish the old look of the website and the new (after development). Samples were asked to analyze the website to see the old and the new after development. 
This test aims to prove the significance of the difference between before and after product development. Therefore, it needs to be tested statistically by t-test correlated (related). Analysis of data from the development of open journal system 3.0 with t-test, which is to test the hypothesis as follows:

Ho: There is no difference in the effectiveness of the search for learning resources by the use of e-journal before development.

Ha: There is no difference in the effectiveness of the search for learning resources by the use of e-journal after development

Analysis of the observed data before and after development with the help of SPSS application, the application used for data processing. Based on the output table Paired Samples Statistics can be seen that in the table are average values obtained from the experimental first stage is 13.31 with a standard deviation obtained at 1.225 and standard error of the mean 171. While the second stage of the experimental results obtained by the average 15.98 with a standard deviation of 1.334 and standard error of the mean 187. the values were obtained from 51 respondents who entered the data.

Based on the output table Paired Samples Correlations obtained correlation value of 0.751 with 0.000 significance (below 0.05). This means on a new design that is after the development of the open journal system 3.0 has contributed a total of 0,751 of the old design, where the e-journal is not in the design and prior to the development.

Paired Samples T Test was used to determine whether there are differences in effectiveness between before and after the development of open journal system 3.0. Tests using two-sided tests with significance level $\alpha=5 \%$ level of significance in this case means taking the risk of wrong in taking the decision to reject the hypothesis that right as much as $5 \%$ (5\% significance or $0: 05$ is the standard measure often used in research. from the table above were obtained $\mathrm{t}$ value is 20.945 and 0.000 significance (below 0.05).

To determine the value of $t$ table can be seen in the statistics table on the 0.05: $2=0.025$ (two-tailed test) with degrees of freedom (df) n-1 or 51-1 $=50$.

According to the table above Paired Samples Test note that the value $t$ count $>t$ table $(20945>2.000)$ and significance $<0.05(0.000<0.05)$, then Ho is rejected. Thus, we can conclude that there are differences in the effectiveness of the development of open journal system 3.0 that is used as a medium of learning resources students. This may imply that the development of open journal system 3.0 that is on the website www.journal.unnes.ac.id/sju an impact on the effectiveness of students in finding the source of learning and ease of downloading articles [5].

\section{Conclusion}

Based on the analysis of research data obtained by value $t$ count $>$ t table $(20945>2.00)$ and significance $<0.05$ $(0.000<0.05)$, then Ho is rejected. Thus, it can be concluded that the development is done by a very effective to be used as a medium of learning resources students. The ease in accessing e-journal give pleasure in finding the source of learning in e-journal website Unnes. Development is done in the header, see three columns and additional information on the sidebar.

\section{References}

1 H. Sotudeh, A. Horri, "Countries positioning in open access journals system: An investigation of citation distribution patterns," Scientometrics, 81, 1, 7-31, ( 2009).

2 J. Willinsky, “Open Journal Systems," Libr. Hi Tech, 23, 4, 504-519, (2005).

3 B. D. Edgar and J. Willinsky, "A survey of the scholarly journals using Open Journal Systems. Scholarly and Research Communication [Електронний ресурс]," Режим доступу, 1, 1, 15, (2005).

4 Y. A. Maretta; A. Munib; S. Sukirman, "Pengembangan Open Journal System Sebagai Sumber Belajar Mahasiswa," Innov. J. Curric. Educ. Technol., 3, 1, (2016).

5 R. Bogdan and S. Biklen, "Qualitative research for education: An introduction to theory and practice." Boston: Allyn and Bacon, (2007).

6 T. Sumaryanto, Metodologi Penelitian 2. Semarang: Universitas Negeri Semarang, (2010).

7 Y. Utanto, G. P. Widhanarto, and Y. A. Maretta, “A web-based portfolio model as the students' final assignment: Dealing with the development of higher education trend," in AIP Conference Proceedings, 1818, 1, 20063 (2017).

8 P. H. Rossi, M. W. Lipsey, and H. E. Freeman, Evaluation: A systematic approach. Sage publications, (2003). 